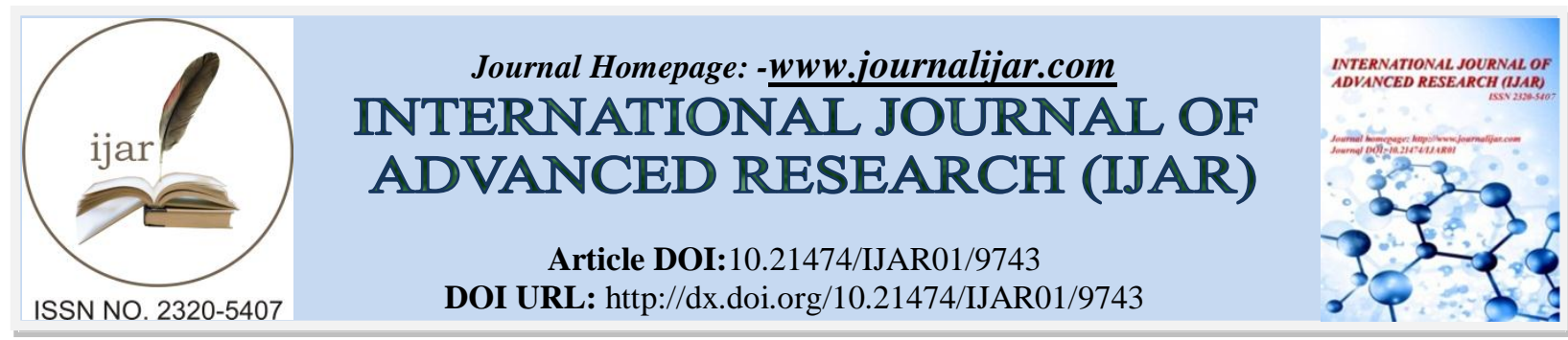

RESEARCH ARTICLE

\title{
IMPACT OF DETERMINANTS ON RETURN ON EQUITY (ROE) ON NIFTY FAST MOVING CONSUMER GOODS (FMCG) INDEX CONSTITUENTS.
}

Mallieswari $\mathbf{R}^{1}$, Aravinda Reddy $\mathrm{M} \mathrm{N}^{\mathbf{1}}$ and Ms. Tanya Prabhakar ${ }^{2}$.

1. Assistant Professor,Ramaiah Institute of Management.

2. Post Graduate,Ramaiah Institute of Management.

\section{Manuscript Info}

Manuscript History

Received: 12 July 2019

Final Accepted: 14 August 2019

Published: September 2019

Key words:-

Nifty, FMCG index, return on equity

(ROE), Correlation, Regression.

\begin{abstract}
This paper examines the impact of various key determinants on return on equity (ROE) on Nifty fast moving consumer goods (FMCG) index constituents. The determinants that are taken for study are fixed assets turnover ratio, total assets turnover ratio, return on assets (ROA), debtequity ratio, interest coverage ratio, inventory turnover ratio, tax efficiency ratio and net profit margin. For the purpose of the study Nifty FMCG index constituents has been taken into consideration which comprises of 15 companies under it. To measure the impact of these variables or determinants secondary data has been analyzed quantitatively using correlation and regression analysis in order to know about the association of variables with ROE, taking it as a dependent variable and the determinants as independent variable. The results obtained from the analysis emphasize the strong connection between return on assets (ROA) and return on equity (ROE) as well as between total assets turnover ratio and return on equity (ROE).
\end{abstract}

Copy Right, IJAR, 2019,. All rights reserved.

\section{Introduction:-}

For many years, all kinds of measures have been used for assessing various changes in the value of the company. These can be broadly classified into four main groups:

1. Traditional accounting measures, mainly based on economic data directly resulting from the standard financial statements;

2. Measures based on residual income category, also known as economic profit or economic value added;

3. Market measures, mainly and substantially related to total return for the owners and market value-added category;

4. Cash measures, based on different types of cash flows and associated with them economic relations.

In recent years, more and more financial measures are used to assess the company value such as EVA (Economic Value Added), MVA (Market Value Added), TSR (Total Shareholder Return) and SVA (Shareholder Value Added). However, for current and potential investors still one of the most important as well as significant indicator is return on equity $(R O E)$ and thus, an important decisive factor for managers across the globe.

Return on equity ratio (ROE) is treated as a crucial measure of a company's earnings performance. The ROE tells common shareholders how effectively their money is being employed or utilized in business. With it, one can determine whether a firm is a profit-creator or a profit-burner and management's profit-earnings efficiency.

In its basis formula ROE can be calculated as follows: 


$$
\mathrm{ROE}=\frac{\text { Net Income }(\mathrm{NI})}{\text { Shareholder Equity }(\mathrm{E})}
$$

The higher a company's return on equity, the better is company's management at employing investors' capital to generate profits. Investors analyze the trend in ROE for individual firms then compare this to historical and industry benchmarks. A rising ROE can signal that a company is able to grow profits without adding new equity into the business, which dilutes the ownership share of existing shareholders.

\section{Review of Literature}

Anna Kijewska [2016] in her study titled "Determinants Of The Return On Equity Ratio (ROE) On The Example Of Companies From Metallurgy And Mining Sector In Poland" present the possibilities of analyzing popular among investors ratio of ROE and identification the determinants of its growth or decline. Traditionally, according to the DuPont formula three indicators are presented as the primary determinants of ROE. The paper shows the possibility of a broader look at the issue and use of the five factors affecting the ROE. This approach reveals that, using various financial and operational strategies one can influence ROE. The analysis was conducted on the example of two Polish companies from mining and metallurgy sector. The study concluded that with ROE broken up into five determinants, causes of change in that ratio can be analyzed in more detail and possible ways to improve it can be indicated.

Lect. Daniel Cîrciumaru, Prof.Marian Siminică and Assoc. prof.Nicu Marcu [2010] in their study titled " A Study OnThe Return On Equity For The Romanian Industrial Companies" is to emphasize the degree the three factors of influence (the leverage, the asset turnover and the net profit margin) determine the return on equity. The survey covered the year 2008 and the data used were extracted from the financial statements of the companies. The sample extraction was performed from a database which included 600 large Romanian companies, namely those who have over 250 employees. As a sampling method, the sampling fraction was used, thus being retained every fifth company from the selection base ordered after the classification of activities from the national economy. This procedure applied, 73 companies were finally included in the sample. The research goal is to test the correlation between the return on equity, on one hand, and its influence factors, on the other hand. The study concluded that only for the net operating profit margin was confirmed a correlation with the return on equity however, the operating margin doesn't explain too much of the level of return on equity. For the total asset turnover and the leverage, the analysis invalidated the existence of a linear correlation.

Muhammad Mubin, Arslan Iqbal and Adnan Hussain [2014] in their study tiltled "Determinant of Return on Assets and Return on Equity and Its Industry Wise Effects: Evidence from KSE (Karachi Stock Exchange)" was performed keeping in view the objective to determine influential factors of profitability using Return on Equity as benchmark with the help of DuPont Identity and also to find out that possible factors are from organizations' inside structure or it is Industry driven. The purpose of the study was served by taking data from 2004 to 2012 of 51 companies of KSE 100. Tools used for testing the hypothesis are multiple regression, one way ANOVA, F-test and T-test. The FStatistics of One Way ANOVA (Analysis of Variance) show that it is Assets Turnover which significantly varies from industry to industry whereas Equity Multiplier and Profit Margin are not much volatile among indifferent industries. Moreover, Adjusted R Square in Panel OLS Analysis was confirming Industry Effect on Newly established firms that they can have the benefit of profitability if they are from Fuel and Energy Sector, Cement Sector and Transport and Communication Sector whereas others Sectors such as Chemicals Sector, Engineering Sectors and Textiles Sectors does not have that leverage. The F-Statistics of One Way ANOVA (Analysis of Variance) show that it is Assets Turnover which significantly varies from industry to industry whereas Equity Multiplier and Profit Margin are not much volatile among indifferent industries. Moreover, Adjusted R Square in Panel OLS Analysis was confirming Industry Effect on Newly established firms that they can have the benefit of profitability if they are from Fuel and Energy Sector, Cement Sector and Transport and Communication Sector whereas others Sectors such as Chemicals Sector, Engineering Sectors and Textiles Sectors does not have that leverage.

D.M.N.S.W. Dissanayake [2011] in his study titled "THE DETERMINANTS OF RETURN ON EQUITY: EVIDENCES FROM SRI LANKAN MICROFINANCE INSTITUTIONS" was carried out to ascertain the significant determinants of Return on Equity in Sri Lankan Microfinance Institutions (MFI). To measure the determinants of microfinance profitability, five measures are used as independent variables which were extracted 
from Damian von Stauffenberg et al (2003) studies Namely, Operating Expense Ratio (OER), Personal Productivity Ratio (PPR), Write-off Ratio (WoR), Cost per Borrower Ratio (CpBR), and Debt/Equity Ratio (DER). Moreover, to determine the variable to measure profit generated, one measure is used as dependent variables. Namely, Return on Equity Ratio (RoER). The criteria for choosing the MFIs were the availability and quality of data for a time period of 6 years (2005 - 2011). The plan of analysis used in study is correlation and multiple regression. Under this study, efficiency and productivity are measured by operating expense ratio, personal productivity ratio and cost per borrower ratio. Financing structure is measured by debt/equity ratio. Meanwhile, Profitability is measured by return on equity ratio. The research concluded stating that the Cost per Borrower and Debt/Equity ratios are statistically significant predictor variables in determining return on equity in a MFI.

Dana Maria and Irnia Bogdana [2014] in her study titled "The analysis of the influence factors affecting the performance of pharmaceutical companies" provides an overview of current situation of the global pharmaceutical industry, with focus placed on the EU pharmaceutical market, including also the Romanian pharmaceutical market evolution synthetized into a SWOT analysis. As main goal the paper identifies several financial performance influence factors at the level of a number of companies from pharmaceutical sector, in order to generate a particular econometric model. The findings of the paper focus on the prediction of Return on Equity (ROE) ratio as the main performance measurement considered significant for the industry our and a large number of factors which contribute to its changes. Thereof, the paper investigates the relationship between various influence indicators or factors resulting from the financial situation of a company and the performance thereof and generates conclusions for the decisions makers at the level of the companies. The regression model obtained in the paper reflects the relationship between the return rate ROE and principal influence factors belonging to the growth dynamic, as well as factors related to liquidity and risk. Other important factors such as R\&D Expenses/Total SG\&A Expenses or Price/Book ratio might be involved in a future econometric model to observe more complex relationships.

\section{Objectives of the study}

The objectives of the study are as follows:

1. To identity the factors which influence ROE of FMCG companies

2. To examine the impact of return on assets (ROA), total asset turnover ratio (TATR), Interest coverage ratio, Fixed assets turnover ratio (FATR), Debt- equity ratio, inventory turnover ratio, tax effect ratio and net profit margin

3. To analyze which of the key determinants strongly impacts on ROE of nifty FMCG index constituents over the year

\section{Scope of the study}

This study focuses on the determinants which impacts the return on equity (ROE) of Nifty FMCG index constituents. For this all companies which come under Nifty FMCG index has been taken into consideration. To analyze the impact past 10 years' data has been collected and measured taking determinants namely fixed assets turnover ratio, total assets turnover ratio, return on assets (ROA), debt-equity ratio, interest-coverage ratio, inventory turnover ratio, tax-efficiency ratio and net profit margin.

\section{Hypothesis}

The following Hypothesis have been made:

\section{Hypothesis1:}

$\mathrm{H}_{0}$ : There is no significant relationship between fixed asset turnover ratio (FATR) and ROE

$\mathrm{H}_{1}$ : There is a significant relationship between fixed asset turnover ratio (FATR) and ROE

\section{Hypothesis 2:}

$\mathrm{H}_{0}$ : There is no significant relationship between total assets turnover ratio and ROE

$\mathrm{H}_{1}$ : There is a significant relationship between total assets turnover ratio and ROE

\section{Hypothesis 3:}

$\mathrm{H}_{0}$ : There is no significant relationship between return on assets (ROA) and ROE

$\mathrm{H}_{1}$ : There is a significant relationship between return on assets (ROA) and ROE

\section{Hypothesis 4:}

$\mathrm{H}_{0}$ : There is no significant relationship between debt-equity ratio and ROE 
$\mathrm{H}_{1}$ : There is a significant relationship between debt-equity ratio and $\mathrm{ROE}$

\section{Hypothesis 5:}

$\mathrm{H}_{0}$ : There is no significant relationship between interest coverage ratio and ROE

$\mathrm{H}_{1}$ : There is a significant relationship between interest coverage ratio and ROE

\section{Hypothesis 6:}

$\mathrm{H}_{0}$ : There is no significant relationship between inventory turnover ratio and ROE

$\mathrm{H}_{1}$ : There is a significant relationship between inventory turnover ratio and ROE

\section{Hypothesis 7:}

$\mathrm{H}_{0}$ : There is no significant relationship between tax effect ratio and ROE

$\mathrm{H}_{1}$ : There is a significant relationship between tax effect ratio and ROE

\section{Hypothesis 8:}

$\mathrm{H}_{0}$ : There is no significant relationship between net profit margin and ROE

$\mathrm{H}_{1:}$ There is a significant relationship between net profit margin and ROE

\section{Data and Methodology:-}

Return on equity (ROE) of various sectors or industries is impacted by many different determinants or variables. According to DuPont three steps model the major components of ROE are operating efficiency, Assets use efficiency and financial leverage. Further according to DuPont five steps model interest expense rate and tax retention rate are added to the model.

For conducting this study secondary data of past 10 years from 2008-2017 have been taken from capitaline database and money control.

For the purpose of the study correlation analysis has been done to identify the factors which influence ROE of FMCG companies and regression analysis has been done to find out the impact of variables on ROE and which variable has relatively more effect on ROE compared to other variables.

\section{Analysis, Results and Discussion:-}

Table 1:-Correlation between fixed assets turnover ratio and ROE

\begin{tabular}{|l|l|c|c|}
\hline \multirow{2}{*}{ ROE } & & ROE & $\begin{array}{c}\text { Fixed assets } \\
\text { turnover ratio }\end{array}$ \\
\hline \multirow{3}{*}{ Fixed assets turnover ratio } & Pearson Correlation & 1 & -.035 \\
\cline { 2 - 4 } & Sig. (2-tailed) & & .674 \\
\cline { 2 - 4 } & $\mathrm{N}$ & 150 & 150 \\
\cline { 2 - 4 } & Pearson Correlation & -.035 & 1 \\
\cline { 2 - 4 } & Sig. (2-tailed) & .674 & 150 \\
\cline { 2 - 4 } & $\mathrm{N}$ & 150 & 150 \\
\hline
\end{tabular}

Table 2:-Shows R-square and adjusted R-square values

\begin{tabular}{|l|c|c|c|c|}
\hline Model & $\mathbf{R}$ & R Square & Adjusted R Square & Std. Error of the Estimate \\
\hline 1 & $.035^{\mathrm{a}}$ & .001 & -.006 & 31.49131 \\
\hline a. Predictors: (Constant), Fixed assets turnover ratio \\
\hline
\end{tabular}


Table 3:-Regression table of ROE and fixed assets turnover ratio Coefficients ${ }^{\mathrm{a}}$

\begin{tabular}{|l|l|c|c|c|c|c|}
\hline \multicolumn{2}{|l|}{ Model } & \multicolumn{2}{|l|}{ Unstandardized Coefficients } & $\begin{array}{c}\text { Standardized } \\
\text { Coefficients }\end{array}$ & \multirow{2}{*}{ Sig. } & \\
\cline { 3 - 6 } \multicolumn{2}{|l|}{1} & B & Std. Error & Beta & & \\
\hline & (Constant) & 37.635 & 4.883 & & 7.707 & .000 \\
\cline { 2 - 6 } & Fixedassetsturnoverratio & -.344 & .815 & -.035 & -.422 & .674 \\
\hline \multicolumn{2}{|l|}{ a. Dependent Variable: ROE } & & & & \\
\hline
\end{tabular}

\section{Interpretation:}

From the above table it is interpreted that there is an indirect weak correlation between fixed assets ratio and return on equity (ROE) and is also not significantly correlated. The R-square value is 0.001 and adjusted R-squared value is -0.006 hence, $\mathrm{ROE}$ is not dependent upon fixed assets turnover ratio.

Table 4:-Correlation between total assets ratio and ROE

\begin{tabular}{|l|l|c|c|}
\hline \multicolumn{2}{|c|}{ Correlations } & ROE & $\begin{array}{c}\text { Total assets turnover } \\
\text { ratio }\end{array}$ \\
\hline \multirow{4}{*}{ ROE } & & & $.768^{* *}$ \\
\hline \multirow{3}{*}{ Total assets turnover ratio } & Pearson Correlation & 1 & .000 \\
\cline { 2 - 4 } & Sig. (2-tailed) & 150 & 150 \\
\cline { 2 - 4 } & $\mathrm{N}$ & $.768^{* *}$ & 1 \\
\hline & Pearson Correlation & .000 & 150 \\
\cline { 2 - 4 } & Sig. (2-tailed) & 150 & \\
\cline { 2 - 4 } & $\mathrm{N}$ & & \\
\hline **. Correlation is significant at the 0.01 level (2-tailed). & & \\
\hline
\end{tabular}

Table 5:-Shows R-square and adjusted R-square value

\begin{tabular}{|l|c|c|c|c|}
\hline Model & $\mathrm{R}$ & $\mathrm{R}$ Square & Adjusted R Square & $\begin{array}{c}\text { Std. Error of the } \\
\text { Estimate }\end{array}$ \\
\hline 1 & $.768^{\mathrm{a}}$ & .590 & .587 & 20.17695 \\
\hline \multicolumn{2}{l}{ Predictors: (Constant), total assets turnover ratio } \\
\hline
\end{tabular}

Table 6:-Regression table of total assets turnover ratio and ROE

\begin{tabular}{|l|l|c|c|c|c|c|}
\hline \multicolumn{2}{|l|}{ Model } & \multicolumn{2}{l|}{ Unstandardized Coefficients } & $\begin{array}{c}\text { Standardized } \\
\text { Coefficients }\end{array}$ & \multirow{2}{*}{ Sig. } \\
\cline { 3 - 5 } \multicolumn{2}{|l|}{1} & $\mathrm{~B}$ & Std. Error & Beta & & \\
\hline & $\begin{array}{l}\text { (Constant) } \\
\text { Total assets turnover } \\
\text { ratio }\end{array}$ & 12.740 & 2.803 & & .992 & .323 \\
\hline \multicolumn{2}{|l|}{ a. Dependent Variable: ROE } & .860 & .768 & 14.593 & .000 \\
\hline
\end{tabular}

\section{Interpretation:}

From the above table it can be interpreted that there is moderate degree of positive correlation ( 0.768$)$ between total assets turnover ratio and ROE and is also significantly correlated as p-value is less than 0.05 . From the results of regression value of R-square is 0.590 and adjusted R-square is 0.589 which suggests that ROE to some extent is dependent upon total assets turnover ratio.

Table 7:-Correlation between return on assets (ROA) and ROE

\begin{tabular}{|l|c|c|c|}
\hline & & ROE & ROA \\
\hline \multirow{3}{*}{ ROE } & Pearson Correlation & 1 & $.788^{* * *}$ \\
\cline { 2 - 4 } & Sig. (2-tailed) & & .000 \\
\cline { 2 - 4 } & $\mathrm{N}$ & 150 & 150 \\
\hline
\end{tabular}




\begin{tabular}{|l|c|c|c|}
\hline \multirow{3}{*}{ ROA } & Pearson Correlation & $.788^{* *}$ & 1 \\
\cline { 2 - 4 } & Sig. (2-tailed) & .000 & 150 \\
\cline { 2 - 4 } & $\mathrm{N}$ & 150 & \\
\hline **. Correlation is significant at the 0.01 level (2-tailed).
\end{tabular}

Table 8:-Shows R-square and adjusted R-square values

\begin{tabular}{|l|c|c|c|c|}
\hline Model & $\mathrm{R}$ & $\mathrm{R}$ Square & Adjusted R Square & $\begin{array}{c}\text { Std. Error of the } \\
\text { Estimate }\end{array}$ \\
\hline 1 & $.788^{\mathrm{a}}$ & .621 & .619 & 19.38917 \\
\hline \multicolumn{2}{l}{} \\
a. Predictors: (Constant), ROA
\end{tabular}

Table 9:-Regression table of return on assets(ROA) and ROE

\begin{tabular}{|c|c|c|c|c|c|c|}
\hline \multicolumn{2}{|c|}{ Model } & \multicolumn{2}{|c|}{ Unstandardized Coefficients } & \multirow{2}{*}{$\begin{array}{c}\text { Standardized } \\
\text { Coefficients } \\
\text { Beta }\end{array}$} & \multirow[t]{2}{*}{$\mathrm{T}$} & \multirow[t]{2}{*}{ Sig. } \\
\hline & & B & Std. Error & & & \\
\hline \multirow[t]{2}{*}{1} & (Constant) & .800 & 2.752 & & .291 & .772 \\
\hline & ROA & 2.206 & .142 & .788 & 15.585 & .000 \\
\hline \multicolumn{3}{|c|}{ a. Dependent Variable: ROE } & & & & \\
\hline
\end{tabular}

From the above table it can be seen that there exists high degree of positive correlation (0.788) between return on assets (ROA) and ROE and is also significantly correlated as p-value is less than 0.05 . Moreover, from the R-square value (0.621) and adjusted R-square value (0.619) it can be said that ROE is significantly dependent on ROA.

Table 10:-Correlation between debt-equity ratio and ROE

\begin{tabular}{|l|l|r|r|}
\hline \multirow{4}{*}{ ROE } & & ROE & \multicolumn{1}{|c|}{ debt-equity } \\
\cline { 2 - 4 } & Pearson Correlation & 1 & $-.357^{* *}$ \\
\cline { 2 - 4 } & Sig. (2-tailed) & 150 & .000 \\
\cline { 2 - 4 } debt-equity & $\mathrm{N}$ & $-.357^{* *}$ & 150 \\
\cline { 2 - 4 } & Pearson Correlation & .000 & 1 \\
\cline { 2 - 4 } & Sig. (2-tailed) & 150 & 150 \\
\cline { 2 - 4 } & $\mathrm{N}$ & \multicolumn{2}{|l}{} \\
\hline \multirow{2}{*}{$* *$ Correlation is significant at the 0.01 level (2-tailed). }
\end{tabular}

Table 11:-Shows R-square and adjusted R-Square values

\begin{tabular}{|l|c|c|c|c|}
\hline Model & $\mathrm{R}$ & $\mathrm{R}$ Square & Adjusted R Square & $\begin{array}{c}\text { Std. Error of the } \\
\text { Estimate }\end{array}$ \\
\hline 1 & $.357^{\mathrm{a}}$ & .127 & .121 & 29.43541 \\
\hline \multicolumn{2}{|l}{ a. Predictors: (Constant), debt-equity } & \\
\hline
\end{tabular}

Table 12:-Regression table of debt-equity ratio and ROE

\begin{tabular}{|l|l|c|c|c|c|c|}
\hline \multicolumn{2}{|l|}{ Model } & \multicolumn{2}{|c|}{ Unstandardized Coefficients } & t & \multirow{2}{*}{ Sig. } \\
\cline { 3 - 5 } \multicolumn{1}{|l|}{1} & B & Std. Error & Beta & & \\
\cline { 2 - 6 } & (Constant) & 42.613 & 2.806 & & 15.187 & .000 \\
\hline \multicolumn{2}{|l}{ a. Depend-equity } & -19.754 & 4.250 & -.357 & -4.648 & .000 \\
\hline
\end{tabular}

\section{Interpretation:}

From the above table it can be interpreted that there is an indirect weak correlation (-0.357) between debt-equity ratio and ROE but is significantly correlated as p-value is less than 0.05 . Moreover, from the R-square value $(0.127)$ 
and adjusted R-square value (0.121) it can be said that ROE is not dependent on debt-equity ratio but the relationship between the variables is significant.

Table 13:-Correlation between interest coverage ratio and ROE

\begin{tabular}{|l|l|c|c|}
\hline \multicolumn{2}{|c|}{ Correlations } & ROE & $\begin{array}{c}\text { Interest coverage } \\
\text { ratio }\end{array}$ \\
\hline \multirow{3}{*}{ ROE } & & & $.322^{* *}$ \\
& Pearson Correlation & 1 & .000 \\
\cline { 2 - 4 } & Sig. (2-tailed) & & 150 \\
\cline { 2 - 4 } & $\mathrm{N}$ & $.322^{* *}$ & 1 \\
\hline \multirow{3}{*}{ Interest coverage ratio } & Pearson Correlation & .000 & 150 \\
\cline { 2 - 4 } & Sig. (2-tailed) & 150 & \\
\cline { 2 - 4 } & $\mathrm{N}$ & \multicolumn{2}{|l}{} \\
\hline \multirow{2}{*}{$* *$. Correlation is significant at the 0.01 level (2-tailed). }
\end{tabular}

Table 14:-Shows R-square and adjusted R- square values

\begin{tabular}{|l|c|c|c|c|}
\hline Model & $\mathrm{R}$ & $\mathrm{R}$ Square & Adjusted R Square & $\begin{array}{c}\text { Std. Error of the } \\
\text { Estimate }\end{array}$ \\
\hline 1 & $.322^{\mathrm{a}}$ & .104 & .098 & 29.83340 \\
\hline a. Predictors: (Constant), interest coverage ratio
\end{tabular}

Table 15:-Regression table of interest coverage ratio and ROE

\begin{tabular}{|c|c|c|c|c|c|c|}
\hline \multirow{2}{*}{\multicolumn{2}{|c|}{ Model }} & \multicolumn{2}{|c|}{$\begin{array}{l}\text { Unstandardized } \\
\text { Coefficients }\end{array}$} & \multirow{2}{*}{$\begin{array}{c}\begin{array}{c}\text { Standardized } \\
\text { Coefficients }\end{array} \\
\text { Beta }\end{array}$} & \multirow[t]{2}{*}{$\mathbf{t}$} & \multirow[t]{2}{*}{ Sig. } \\
\hline & & B & Std. Error & & & \\
\hline \multirow[t]{2}{*}{1} & (Constant) & 30.661 & 2.744 & & 11.175 & .000 \\
\hline & Interest coverage ratio & .060 & .015 & .322 & 4.136 & .000 \\
\hline \multicolumn{3}{|c|}{ a. Dependent Variable: ROE } & & & & \\
\hline
\end{tabular}

\section{Interpretation:}

From the above table it can be interpreted that there exists a very weak positive correlation $(0.322)$ between interest coverage ratio and ROE and is also significantly correlated as p-value is less than 0.05 . Moreover, from the values of R-square (0.104) and adjusted R-Square (0.098) it can be seen that ROE is not dependent upon interest coverage ratio still there is exists a significant association between the two variables.

Table 16:-Correlation between inventory turnover ratio and ROE

\begin{tabular}{|l|l|c|c|}
\hline \multirow{4}{*}{ ROE } & & ROE & Inventory turnover ratio \\
\hline & Pearson Correlation & 1 & .003 \\
\cline { 2 - 4 } & Sig. (2-tailed) & & .973 \\
\cline { 2 - 4 } & $\mathrm{N}$ & 150 & 150 \\
\hline \multirow{3}{*}{ Inventory turnover ratio } & Pearson Correlation & .003 & 1 \\
\cline { 2 - 4 } & Sig. (2-tailed) & .973 & 150 \\
\cline { 2 - 4 } & $\mathrm{N}$ & 150 & 1 \\
\hline
\end{tabular}

Table 17:-Shows R-square and adjusted R- square

\begin{tabular}{|l|c|c|c|c|}
\hline Model & $\mathrm{R}$ & $\mathrm{R}$ Square & Adjusted R Square & $\begin{array}{c}\text { Std. Error of the } \\
\text { Estimate }\end{array}$ \\
\hline 1 & $.003^{\mathrm{a}}$ & .000 & -.007 & 31.51014 \\
\hline \multicolumn{2}{|l}{ a. Predictors: (Constant), inventory turnover ratio } \\
\hline
\end{tabular}


Table 18:-Regression table of inventory turnover ratio and ROE

\begin{tabular}{|c|c|c|c|c|c|c|}
\hline \multicolumn{2}{|c|}{ Model } & \multicolumn{2}{|c|}{ Unstandardized Coefficients } & \multirow{2}{*}{$\begin{array}{c}\text { Standardized } \\
\text { Coefficients } \\
\text { Beta }\end{array}$} & \multirow[t]{2}{*}{$\mathrm{t}$} & \multirow[t]{2}{*}{ Sig. } \\
\hline & & $\mathrm{B}$ & Std. Error & & & \\
\hline \multirow[t]{2}{*}{1} & (Constant) & 35.789 & 3.769 & & 9.495 & .000 \\
\hline & $\begin{array}{l}\text { Inventory turnover } \\
\text { ratio }\end{array}$ & .006 & .190 & .003 & .034 & .973 \\
\hline & dent Variable: ROE & & & & & \\
\hline
\end{tabular}

\section{Interpretation:}

From the above table it can be interpreted that there does not exist any correlation (0.003) between inventory turnover ratio and ROE. Moreover, from the R-square value (0.00) and adjusted R-square value (-0.007) it can be seen that there does not exists any dependency of ROE on inventory turnover ratio and is also not significantly related as p-value is more than 0.05 .

Table 19Correlation between tax efficiency ratio and ROE

\begin{tabular}{|l|l|c|c|}
\hline \multirow{4}{*}{ ROE } & & ROE & Tax efficiency ratio \\
\cline { 2 - 4 } & Pearson Correlation & 1 & $.377^{* *}$ \\
\cline { 2 - 4 } & Sig. (2-tailed) & 150 & .000 \\
\cline { 2 - 4 } & $\mathrm{N}$ & $.377^{* *}$ & 150 \\
\hline \multirow{3}{*}{ Tax efficiency ratio } & Pearson Correlation & .000 & 1 \\
\cline { 2 - 4 } & Sig. (2-tailed) & 150 & 150 \\
\cline { 2 - 4 } & $\mathrm{N}$ & \multicolumn{2}{|l}{} \\
\hline \multirow{2}{*}{$* *$ Correlation is significant at the 0.01 level (2-tailed). }
\end{tabular}

Table 20:-Shows R-square and adjusted R-square values

\begin{tabular}{|l|c|c|c|c|}
\hline Model & $\mathrm{R}$ & $\mathrm{R}$ Square & Adjusted R Square & $\begin{array}{c}\text { Std. Error of the } \\
\text { Estimate }\end{array}$ \\
\hline 1 & $.377^{\mathrm{a}}$ & .142 & .136 & 29.18583 \\
\hline \multicolumn{2}{|l}{ a. Predictors: (Constant), tax efficiency ratio } & \\
\hline
\end{tabular}

Table 21:-Regression table of tax efficiency ratio and ROE

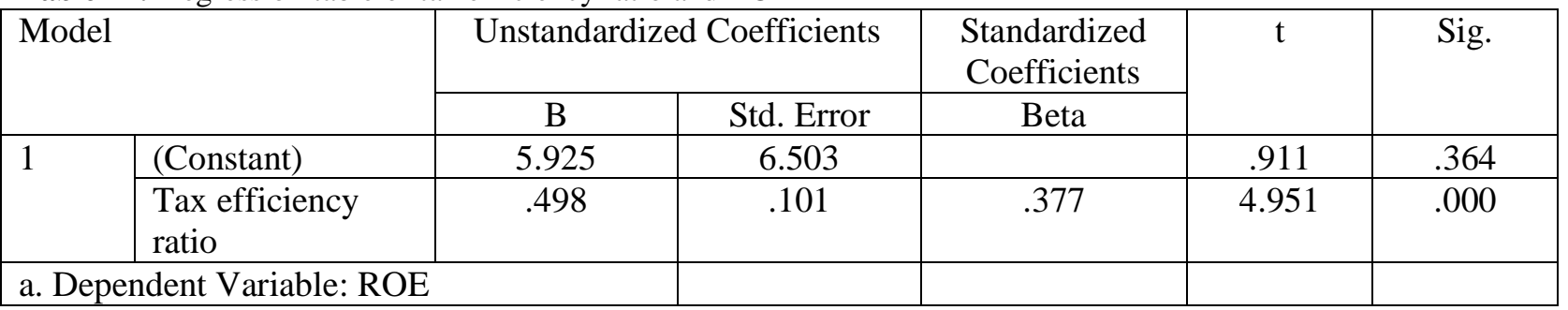

\section{Interpretation:}

From the above table it can be interpreted that there exists a weak positive correlation (0.377) between tax efficiency ratio and ROE. Moreover, from the values of R-square (0.142) and adjusted R-square (0.136) it can be seen that there is no dependency of ROE on tax efficiency ratio still there exists a significant association as p-value is less than 0.05 .

Table 22:-Correlation between net profit margin and ROE

\begin{tabular}{|l|l|c|c|}
\hline \multirow{2}{*}{ ROE } & & ROE & Net profit margin \\
\cline { 2 - 4 } & Pearson Correlation & 1 & $.297^{* *}$ \\
\cline { 2 - 4 } & Sig. (2-tailed) & & .000 \\
\cline { 2 - 4 } & $\mathrm{N}$ & 150 & 150 \\
\hline
\end{tabular}




\begin{tabular}{|l|l|c|c|}
\hline \multirow{3}{*}{ Net profit margin } & Pearson Correlation & $.297^{* *}$ & 1 \\
\cline { 2 - 4 } & Sig. (2-tailed) & .000 & 150 \\
\cline { 2 - 4 } & $\mathrm{N}$ & 150 & \\
\hline$* *$. Correlation is significant at the 0.01 level (2-tailed).
\end{tabular}

Table 23:-Shows R-square and adjusted R-square value

\begin{tabular}{|l|c|c|c|c|}
\hline Model & $\mathrm{R}$ & $\mathrm{R}$ Square & Adjusted R Square & $\begin{array}{c}\text { Std. Error of the } \\
\text { Estimate }\end{array}$ \\
\hline 1 & $.297^{\mathrm{a}}$ & .088 & .082 & 30.08980 \\
\hline \multicolumn{2}{|l}{ a. Predictors: (Constant), net profit margin } \\
\hline
\end{tabular}

Table 24:-Regression table of net profit margin and ROE

\begin{tabular}{|l|l|c|c|c|c|c|}
\hline \multicolumn{2}{|l|}{ Model } & \multicolumn{2}{|c|}{ Unstandardized Coefficients } & $\begin{array}{c}\text { Standardized } \\
\text { Coefficients }\end{array}$ & \multirow{2}{*}{ Sig. } \\
\cline { 3 - 6 } \multicolumn{2}{|l|}{} & B & Std. Error & Beta & \\
\hline \multirow{2}{*}{1} & (Constant) & 23.529 & 4.087 & & 5.757 & .000 \\
\cline { 2 - 6 } & Net profit margin & 1.032 & .273 & .297 & 3.782 & .000 \\
\hline \multicolumn{2}{|l|}{ a. Dependent Variable: ROE } & & & & \\
\hline
\end{tabular}

\section{Interpretation:}

From the above table it can be interpreted that there exists a very weak positive correlation (0.297) between net profit margin and ROE. Moreover, from the values of R-square (0.088) and adjusted R-square value (0.082) it can be seen that ROE is not dependent on net profit margin ratio yet there is a significant association between the variables as p-value is less than 0.05 .

\section{Inference:}

It can be inferred that Fixed assets turnover ratio and inventory turnover ratio cannot be taken as a factor which influences the ROE of FMCG companies. Moreover, as fixed assets turnover ratio and inventory turnover ratio are not significantly correlated with ROE as well as there is no dependency of ROE on fixed assets turnover and inventory turnover ratios hence, it does not have any major impact on ROE of FMCG nifty index constituents. Total assets turnover ratio and return on assets (ROA) can be considered as a factor which impacts ROE of nifty FMCG index constituents and as total turnover assets ratio and ROA are having significant association with ROE as well as there is dependency of ROE on total assets turnover ratio therefore, it can be said that it largely impacts the ROE of nifty FMCG index. Though debt-equity ratio indirectly has a weak impact on ROE as well as non-dependency of ROE on debt-equity ratio gives a reason to not to consider debt-equity ratio as a factor which influences ROE yet its strong statistical association made it a factor which largely impacts ROE. It can be inferred that interest coverage ratio, tax-efficiency ratio and net profit margin does not influence ROE of nifty FMCG companies and hence cannot be included in the factors that influences ROE as correlation between these determinants and ROE is very weak but its significant association made it a factor which largely impacts ROE of nifty FMCG index constituents as their pvalue is less than 0.05 .

\section{Conclusion:-}

The intention of this research is to assert those key determinants or key variables which have an impact over the return on equity (ROE) of nifty FMCG index constituents. The study's findings lead to the conclusion that return on assets (ROA), total assets turnover ratio, debt-equity ratio, interest coverage ratio, tax efficiency ratio and net profit margin ratios are statistically significant variables in determining the return on equity (ROE) of Nifty FMCG index constituents. Adding to that, inventory turnover ratio and fixed assets turnover ratios neither stand significant under correlation test nor under regression test.

\section{References:-}

1. T.S. Grewal, "Financial analysis", Edition 2011, Sultan chand and Sons publications, New-Delhi 
2. Ashish Chawla and Neena Somdhi, "Business research and methodology", Edition 2016, Vikas publications, New Delhi

3. Prasanna Chandra, "Investment analysis and portfolio management", Edition 2016, McGraw- hill publications, New Delhi

4. https://www.researchgate.net/publication/282704962

5. https://www.researchgate.net/publication/272304988

6. https://www.researchersworld.net

7. https://econpapers.repec.org/RePEc:aio:aucsse:v:2:y:2010:i:8:p:44-51

8. https://www.oeconomica.uab.ro/upload/lucrari/1320112/03.pdf

9. https://www.capitaline.com 